\title{
MANAGING THE COMPETITIVENESS OF LIGHT INDUSTRY ENTERPRISES: THE CASE OF UKRAINE
}

\author{
Nataliya Tyukhtenko ${ }^{1}$, Serhit Makarenko ${ }^{2}$, Galina Savina ${ }^{3}$, \\ Natalita OliInyK ${ }^{4}$, Yana Oleksenko ${ }^{5}$, Serhit RybachoK ${ }^{6}$ \\ Kherson State University (Ukraine), Kherson National Technical University (Ukraine)
}

\begin{abstract}
To manage competitiveness, an objective assessment tool is required. An error in choosing a measurement method can lead to the adoption of erroneous management decisions. The purpose of the article is to assess the competitiveness of light industry enterprises in Ukraine, to identify factors ensuring their competitiveness, and to develop recommendations for determining the feasibility of investing in the procurement and implementation of modern innovative technologies. The article summarises the views of the scientific community on features of the development of industrial enterprises in current market conditions, and the need to attract modern innovative technologies as a component in increasing their competitiveness. In determining the level of competitiveness of enterprises, it has been suggested to take into account factors determining the level of information reliability and weapons. To evaluate the individual component competitiveness of the enterprise, it is proposed to calculate an integral assessment based on the use of taxonomic analysis. An analysis of the innovative activities of Ukrainian industrial enterprises has been carried out. A flow chart determining the feasibility of purchasing innovative specialised equipment has been developed; it will simultaneously maximise the likelihood of attracting investment capital, with the simultaneous establishment of business cooperation with state authorities and local government.

KEY WORDS: management, competitiveness index, integral indicator, labour resources, innovative technologies.
\end{abstract}

JEL CODES: M 11, M 12, M 13

DOI:

1 Nataliya Tyukhtenko - Doctor of economic science, professor, Management and Administration Department, Kherson State University, Ukraine

Scientific interests: human resource management, innovative technologies

E-mail: tuhtenko1@gmail.com

2 Serhii Makarenko - Ph.D (Economic), Associate Professor, Management and Administration Department, Kherson State University, Ukraine

Scientific interests: human resource management, enterprise competitiveness, innovative technologies

E-mail: makar0684@gmail.com

3 Galina Savina - Doctor of economic science, professor, Management and Marketing Department, Kherson National Technical University, Ukraine

Scientific interests: human resource management, innovative technologies

E-mail: meng-market@kntu.net.ua

4 Nataliia Oliinyk -Ph.D (Technical), Associate Professor, Economics, Entrepreneurship and Economic Security Department, Kherson National Technical University, Ukraine

Scientific interests: human resource management, enterprise competitiveness

E-mail: nat-o@ukr.net

5 Yana Oleksenko - Postgraduate student, Management and Administration Department, Kherson State University, Ukraine Scientific interests: human resource management, enterprise competitiveness

E-mail: yanochka.oleksenko@gmail.com

6 Serhii Rybachok - Postgraduate student, Management and Administration Department, Kherson State University, Ukraine Scientific interests: human resource management, enterprise competitiveness, innovative technologies

E-mail Rsa@kherson.org 


\section{Introduction}

In today's market conditions, the need to ensure the stable development and the competitiveness of domestic enterprises encourages entrepreneurs and managers to find effective systems and methods for managing economic activity. According to M. Porter (2005), an enterprise's competitiveness is an opportunity to gain competitive advantages, and retain them, in certain areas. A.V. Savchuk (2001) points out that the competitiveness of an enterprise is manifested in the ability to achieve the best results in a competitive market, in a certain activity.

In general, competitiveness represents the ability to withstand competition in comparison with similar entities in a competitive environment. The competitiveness of an entity is determined by the results of market research, and market segmentation (Burtseva T.A., Syzov V.S., Tsen O.A., 2005). The most generalised competitiveness of an enterprise can be defined as the potential or realised ability of an economic entity to function effectively in the long term in a suitable external environment. Consequently, according to the views of some authors (Klymenko S.M., Dubrova O.S., Barabas D.O., Omelianenko T.V., Vakulenko A.V, 2006), the competitiveness of the enterprise is based on the competitive advantages of the enterprise, it determines the ability of an enterprise to withstand competition in a particular market, and it reflects the position of the enterprise relative to its competitors.

The development of an enterprise and an increase in its competitiveness in the current unstable business environment conditions can be achieved only through the effective use of modern methods of managing production resources, and the constant introduction of innovative technologies in all spheres of its economic activity. The innovative activity of industrial enterprises has long been the main condition for their competitiveness, and requires systematic management. By activating innovative development, domestic enterprises will be able to respond promptly to changes in the market environment, quickly overcoming the effects of an economic crisis, and provide social benefits and a reasonable increase in the level of remuneration.

Kot and Pavliuk (2013) consider that the development of an enterprise means qualitative changes and the updating of its economic system and organisational structure, an increase in functioning efficiency on the basis of an improvement of technics, technologies and the organisation of work in all structural divisions, and an improvement in the quality of the products, goods and services which they produce and provide.

In the future, existing competitive advantages will be lost to enterprises that fail to appreciate the importance of the continuous and multifaceted implementation of innovations.

In our opinion, the innovative activity of the enterprise should be based on principles of priority of innovative development, scientific novelty, feasibility studies, legal substantiation, minimisation of risk, and an increase in the competitiveness of both the products and the enterprise as a whole.

Research problem. Issues related to determining the strategic interdependence of the innovative development and competitiveness of the enterprise remain under-researched and not disclosed in periodicals.

Aim of the research. The purpose of the article is to assess the competitiveness of light industry enterprises in Ukraine, to identify factors ensuring their competitiveness, and to make recommendations for determining the feasibility of investing in the procurement and implementation of modern innovative technologies.

Object of the research. The subject of the study is light industry enterprises in Ukraine.

Tasks: the identification of factors ensuring the competitiveness of light industry enterprises; the investigation of different methods and substantiation of the optimal methodological approach to the assessment of the efficiency of business management; the substantiation of the feasibility of attracting modern innovative technologies as a basis for increasing the competitiveness of light industry enterprises.

\section{Methodology and research methods}

The methodological basis of the study consisted of research works by domestic and foreign scientists and leading specialists, and statistical and analytical materials from the state authorities. A questionnaire 
was chosen as the method of data collection for the research. The research was carried out in selected institutions of higher education (Kherson State University), local authorities (the Department for Economic Development and Trade of the Kherson Regional State Administration; the Main Department of the State Fiscal Service of Ukraine in the Kherson region, the Autonomous Republic of Crimea and Sevastopol), trade union organisations (Kherson Regional Inter-Branch Council of Trade Unions), leading enterprises in Kherson (Amalteya, Platan LTD) and public organisations (the MI-KHERSONTS business association). Results are obtained through the use of methods such as: expert, to identify the impact of qualitative and quantitative indicators on the efficiency of the use of labour resources; economic and mathematical, to determine the competitiveness index and the integral indicator of an assessment of the efficiency of the use of labour resources; abstract-logical, for theoretical generalisation and the formulation of conclusions. Given that each expert has a different level of education, experience, and scale of management activity, the coefficient of expert competence was determined using an improved methodological approach. This allowed for the transformation of all qualitative and quantitative evaluating indicators into a single rating scale, taking into account the individual level of practical and scientific training of each of the respondents, and reducing the level of error when using the intuitive group of methods.

\section{Identification of factors ensuring the competitiveness of light industry enterprises}

In economic literature dealing with solving the problem of low competitiveness of industrial enterprises operating in Ukraine, and creating favourable conditions for ensuring a high level of competitiveness in the changing market conditions, much attention is paid to the success factors of an enterprise (Klymenko et al., 2008). Strategic success is talked about when it is ensured over the long term.

In our opinion, a set of market and resource factors are key factors for success. The optimal combination of resource consumption can affect the formation of the long-term competitiveness of the economic entity, and therefore its strategic success.

Some specialists (Klymenko et al., 2008) believe that key success factors have a pronounced industrial character, and are common benchmarks for all businesses in a particular industry.

Our research shows that the set of key success factors in various industries is noticeably different. They can change significantly under the influence of changes in the internal and external business environment. Therefore, an important task is to identify key success factors, and to forecast future changes. In Figure 1, the improved interrelation of success factors and the competitive potential of light industry enterprises is reflected.

One of the fundamental factors related to the need to develop a set of measures aimed at improving the competitiveness of the enterprise in general, and its production in particular, is the uncertainty of the enterprise's functioning environment, as well as the associated impact on its activity of an economic risk factor. In difficult conditions in the functioning of the national economy, it is impossible to avoid economic risk; therefore, in order to strengthen its competitive positions in the market, the management of the enterprise need to constantly determine, in the process of the planning and organisation of activities, the most important factors influencing the decision-making process, sources and magnitude of occurrence of risk, and loss from the occurrence of possible risk situations. And then, on this basis, to develop a set of measures to protect against risk, and ways to increase the level of competitiveness of the enterprise. 


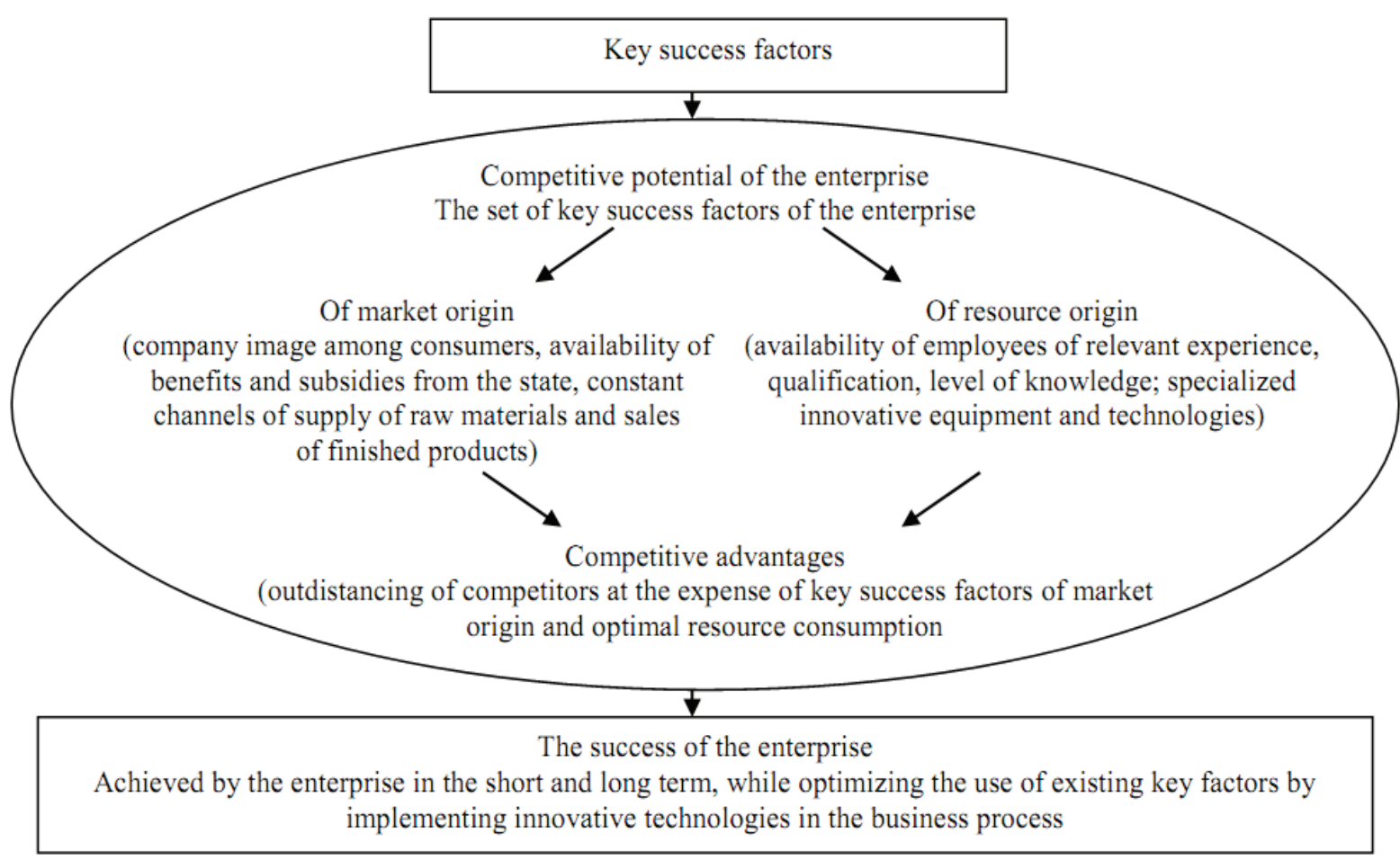

Figure 1. The interrelation of success factors and competitive potential of light industry enterprises.

Source: Author's construction based on Klymenko et al., 2008.

\section{Methodology for assessing the level of an enterprise's competitiveness}

In the current conditions of limited production resources and constant increases in consumer demand for products, work performed and services provided, prosperity can be hoped for only by an enterprise that ensures the production of quality products (work, services) through the introduction of modern innovative technologies and the optimal consumption of available production resources.

In order to achieve long-term success, work to ensure the competitiveness of an enterprise must be carried out in all areas and in all aspects of its activities. In our opinion, when calculating the level of competitiveness of light industry enterprises, it is necessary to take into account factors that determine the level of:

- reliability of information on markets for finished goods and production resources. Without a means of collecting and processing, information systems can neither see a problem itself nor assess the level of competitiveness, and thus cannot take adequate appropriate action. It should be noted that erroneous information can create an even worse situation, since the necessary resources can be directed in the wrong direction;

- technological and resource weapons in production processes. Without resources under the existing innovative technology, it is impossible to organise the appropriate response; and, conversely, the quality of resources in the system is always there, but the technology needed is not always there, although theoretically it can be represented;

- adaptability to the changing external conditions of the enterprise's organisational system (the availability of sufficient time to organise the appropriate response). Without enough time, even with information and sufficient weaponry of the system, nothing can be done to eliminate the threats. 
The time factor is manifested in the following main directions:

- optimisation of the production cycle duration;

- adherence to the calendar and volume production plan, in accordance with the terms of contracts;

- rapid reorganisation of production processes in accordance with changes in the conditions of the operation of the enterprise.

The results of studies by the authors (Tyuhtenko et al., 2018) show that since all these factors must be present at the same time, the level of competitiveness can only be calculated if they are combined in a logical multiplication, that is, the competitiveness index should be calculated as follows:

$$
\mathrm{I}_{\mathrm{c}}=\mathrm{I}_{\mathrm{inf}} * \mathrm{I}_{\mathrm{w},}
$$

where

$I_{c}=$ competitiveness index

$\mathrm{I}_{\text {inf }}=$ information reliability index

$I_{w}=$ weapon effectiveness index

The information reliability index can be calculated as a multiplication of the indices of information reliability on markets for finished goods and production resources, namely:

$$
\mathrm{I}_{\text {inf }}=\mathrm{I}_{\text {inf.fin.g }} * \mathrm{I}_{\text {inf.res }},
$$

where

$I_{\text {inf.fin.g }}=$ information reliability index on markets for finished goods

$\mathrm{I}_{\text {inf.res }}=$ information reliability index on markets for production resources

Indices of information reliability on markets for finished goods and production resources can be calculated as the relation of all reliable forecasts (based on enterprise data) to the total number of forecasts made on the basis of available information.

If the above index is equal to one, the magnitude of the threats will be equal to the magnitude of the possible losses. If the information is not qualitative, then the magnitude of the threats will far exceed the possible losses, as in this case there is a need to increase insurance reserves throughout the system.

The information reliability index may be estimated by experts in the field of production. At the same time, it should be borne in mind that forecasting scenarios and enterprise development programmes are conducted using intuitive forecasting methods without the use of specialised software. In this case, there is almost no use of mathematical models and information technologies that will allow the estimation of the level of competence of the experts involved, and to increase the reliability level of predictive assumptions made. Based on the results of the research, the authors (Tyukhtenko, Makarenko, 2016) proposed to determine the coefficient of experts' competence, depending on experience (position), educational level, academic degree, academic title, and other factors relevant to the object of the research. At the same time, it would also be appropriate to take into account the level of fluctuation in the respective qualifications within the group studied when determining the expert competence coefficient. This will allow for the transformation of all qualitative and quantitative evaluating indicators into a single rating scale. The proposed approach can be used not only in determining the experts' competence level, but also in assessing the qualification level of employees (Q1), and determining the value of 1 point of qualification competencies (Table 1) in the relevant economic area. 
Table 1. Example of calculating the cost of 1 point of expert employee qualification competencies.

\begin{tabular}{|c|c|c|c|c|c|c|c|c|c|c|}
\hline $\begin{array}{c}\text { Employ- } \\
\text { ee }\end{array}$ & $\begin{array}{c}\text { Educa- } \\
\text { tion, } \\
\text { points }\end{array}$ & Coef.1 & $\begin{array}{c}\text { Experi- } \\
\text { ence, } \\
\text { months }\end{array}$ & Coef.2 & $\begin{array}{c}\text { Producti- } \\
\text { vity, } \\
\text { UAH / hour }\end{array}$ & Coef.3 & $\frac{\sum \text { Coef }}{\mathbf{3}}$ & $\begin{array}{c}\text { QI, } \\
\text { points }\end{array}$ & $\begin{array}{c}\text { Average } \\
\text { monthly } \\
\text { salary, UAH }\end{array}$ & $\begin{array}{c}\text { Cost of 1 } \\
\text { quality } \\
\text { point }\end{array}$ \\
\hline № 1 & 5 & 0.6 & 87 & 0.8077 & 110 & 0.8 & 0.7359 & 1.3589 & 7500 & 5519.23 \\
\hline № 2 & 7 & 0.2 & 75 & 0.9615 & 145 & 0.4957 & 0.5524 & 1.8103 & 9000 & 4971.57 \\
\hline № 3 & 3 & 1.0 & 72 & 1.0 & 124 & 0.6783 & 0.8928 & 1.1201 & 8000 & 7142.03 \\
\hline № 4 & 4 & 0.8 & 123 & 0.3462 & 118 & 0.7304 & 0.6255 & 1.5986 & 7400 & 4628.92 \\
\hline № 5 & 6 & 0.4 & 78 & 0.9231 & 167 & 0.3043 & 0.5425 & 1.8434 & 9500 & 5153.51 \\
\hline № 6 & 8 & 0.0 & 128 & 0.2821 & 202 & 0.0 & 0.0940 & 10.6364 & 10500 & 987.18 \\
\hline № 7 & 5 & 0.6 & 150 & 0.0 & 185 & 0.1478 & 0.2493 & 4.0116 & 11000 & 2742.03 \\
\hline № 8 & 3 & 1.0 & 91 & 0.7564 & 87 & 1.0 & 0.9188 & 1.0884 & 8500 & 7809.83 \\
\hline & Max=8 & & Max $=150$ & & Max $=202$ & & & & & \\
\hline & Min=3 & & Min=72 & & Min=87 & & & & & \\
\hline
\end{tabular}

Source: Developed by the authors.

The calculations show that, according to the proposed methodology, the highest qualification level is the employee number $6(\mathrm{Q} 1=10.6364$ points $)$. Also, the cost of 1 quality point of the specified employee is the lowest, which indicates his/her high competitiveness level in a certain production area.

The use of the methodical approach mentioned above in determining the level of competence of experts, based on the calculations obtained for the three indicators of assessment, revealed their levels of competence as follows: expert $1-5.79 \%$; expert $2-7.71 \%$; expert 3 - 4.77\%; expert $4-6.81 \%$; expert $5-7.86 \%$; expert 6 - 45.32\%; expert 7 - 17.09\%; expert 8 - 4.64\%.

For light industry enterprises operating on terms of raw materials, the information reliability index on the market for finished goods is equal to one, since the volume and region of sale of the finished goods are known in advance.

We propose finding the weapon effectiveness with the formula:

$$
I_{W}=\frac{P_{\text {act }}}{P_{\text {max }}}
$$

where

$\mathrm{P}_{\mathrm{act}}=$ the enterprise's actual profit for the reporting period

$\mathrm{P}_{\max }=$ the maximum possible amount of profit made by the enterprise for the reporting period

The maximum possible profit is calculated on condition that the enterprise operates in a market of perfect competition, and in the reporting period sold the whole volume of production at the planned price without possible discounts.

An example of calculating the competitiveness index of the light industry enterprise

Platan LTD (Kherson, Ukraine) is shown in Table 2. 
Table 2. An example of calculating the competitiveness index of the light industry enterprise Platan LTD.

\begin{tabular}{|l|c|c|c|c|c|c|}
\hline \multirow{2}{*}{ Indicator } & \multicolumn{7}{c|}{ Years } \\
\cline { 2 - 7 } & $\mathbf{2 0 1 3}$ & $\mathbf{2 0 1 4}$ & $\mathbf{2 0 1 5}$ & $\mathbf{2 0 1 6}$ & $\mathbf{2 0 1 7}$ & $\mathbf{2 0 1 8}$ \\
\hline $\begin{array}{l}\text { Production volume, thousands of } \\
\text { units }\end{array}$ & 4.16 & 8.19 & 12.22 & 16.25 & 20.28 & 21.28 \\
\hline Net sales revenue, thousand UAH & 1274 & 3096.5 & 4978 & 8122 & 12843 & 13908 \\
\hline $\begin{array}{l}\text { Cost of production, thousand } \\
\text { UAH }\end{array}$ & 1044 & 2559.5 & 4149 & 6768 & 11467 & 12689 \\
\hline Actual profit, thousand UAH & 230 & 537 & 829 & 1354 & 1376 & 1219 \\
\hline $\begin{array}{l}\text { The maximum possible amount of } \\
\text { profit, тис. rpH. }\end{array}$ & 313.5 & 768 & 1245 & 1692 & 1720 & 1828.5 \\
\hline The weapon effectiveness & 0.73 & 0.7 & 0.67 & 0.8 & 0.8 & 0.67 \\
\hline Marginal revenue & - & 452.2 & 466.9 & 780.1 & 1171.5 & 1065.0 \\
\hline Marginal cost & - & 376.1 & 394.4 & 649.9 & 1166.0 & 1222.0 \\
\hline Information reliability index & 0.74 & 0.74 & 0.76 & 0.75 & 0.9 & 0.78 \\
\hline Competitiveness index & 0.54 & 0.52 & 0.51 & 0.60 & 0.72 & 0.52 \\
\hline
\end{tabular}

Source: Developed by the authors.

For evaluating the individual component competitiveness of the enterprise, we propose to calculate the integral assessment based on the use of taxonomic analysis as follows:

- Stage 1: the formation of a system of information space for assessing the individual component competitiveness of the enterprise

- Stage 2: the formation of a matrix of standardised attribute values

- Stage 3: the formation of a 'reference point'

- Stage 4: the calculation of the Euclidean distance

- Stage 5: the calculation of the values of the integral indicator

- Stage 6: drawing conclusions based on the data obtained.

The example of the leading light industry enterprise Platan LTD was carried out with an integral indicator of labour efficiency.

In Table 3, generalised recommendations are given on indicators that need to be taken into account when assessing the efficiency of the use of labour resources.

Table 3. Generalised recommendations on indicators that need to be taken into account when assessing the efficiency of the use of labour resources.

\begin{tabular}{|c|c|c|c|c|c|c|c|}
\hline \multirow{2}{*}{$\begin{array}{c}\text { call } \\
\text { number }\end{array}$} & \multirow{2}{*}{ Indicator } & \multicolumn{6}{|c|}{ Years } \\
\cline { 3 - 8 } & & $\mathbf{2 0 1 3}$ & $\mathbf{2 0 1 4}$ & $\mathbf{2 0 1 5}$ & $\mathbf{2 0 1 6}$ & $\mathbf{2 0 1 7}$ & $\mathbf{2 0 1 8}$ \\
\hline A1 & $\begin{array}{c}\text { Admission workforce } \\
\text { turnover ratio }\end{array}$ & 0.109 & 0.316 & 0.208 & 0.316 & 0.108 & 0.212 \\
\hline A2 & Labor turnover ratio & 0.213 & 0.104 & 0.158 & 0.212 & 0.148 & 0.104 \\
\hline A3 & $\begin{array}{c}\text { Average monthly salary of } \\
\text { staff, UAH/ person }\end{array}$ & 3018.9 & 3874.4 & 4574.9 & 4878.7 & 5684.4 & 6357.8 \\
\hline A4 & $\begin{array}{c}\text { Productivity of personnel, } \\
\text { thousand UAH/ person }\end{array}$ & 15092.7 & 18748.3 & 22748.9 & 25967.3 & 30745.8 & 37489.2 \\
\hline
\end{tabular}

Source: Developed by the authors. 
In Table 4, the mean value and standard deviation were calculated for a group of indicators characterising the efficiency of labour utilisation.

Table 4. Calculation of mean and standard deviation.

\begin{tabular}{|c|c|c|c|c|c|c|c|c|}
\hline Indicator & $\mathbf{2 0 1 3}$ & $\mathbf{2 0 1 4}$ & $\mathbf{2 0 1 5}$ & $\mathbf{2 0 1 6}$ & $\mathbf{2 0 1 7}$ & $\mathbf{2 0 1 8}$ & $\overline{\mathbf{A}}$ & $\delta$ \\
\hline $\mathrm{A} 1$ & 0.109 & 0.316 & 0.208 & 0.316 & 0.108 & 0.212 & 0.21 & 0.085 \\
\hline $\mathrm{A} 2$ & 0.213 & 0.104 & 0.158 & 0.212 & 0.148 & 0.104 & 0.16 & 0.044 \\
\hline $\mathrm{A} 3$ & 3018.9 & 3874.4 & 4574.9 & 4878.7 & 5684.4 & 6357.8 & 4731.52 & 1100.506 \\
\hline $\mathrm{A} 4$ & 15092.7 & 18748.3 & 22748.9 & 25967.3 & 30745.8 & 37489.2 & 25132.03 & 7440.108 \\
\hline
\end{tabular}

Source: Developed by the authors.

Standardised indicator values, intermediate values of the reference point, Euclidean distance, and integral indicator are shown in Table 5.

Table 5. Standardised values of indicators, intermediate values of a reference point, Euclidean distance and integral index.

\begin{tabular}{|c|c|c|c|c|c|c|c|c|c|c|}
\hline $\begin{array}{c}\text { The } \\
\text { default } \\
\text { value }\end{array}$ & $\mathbf{2 0 1 3}$ & $\mathbf{2 0 1 4}$ & $\mathbf{2 0 1 5}$ & $\mathbf{2 0 1 6}$ & $\mathbf{2 0 1 7}$ & $\mathbf{2 0 1 8}$ & $\begin{array}{c}\text { Reference } \\
\text { point }\end{array}$ & $\mathbf{C}_{\mathbf{0}}$ & $\mathbf{S}_{\mathbf{0}}$ & $\mathbf{C}_{\mathbf{0}}$ \\
\hline A1 & -1.2098 & 1.2334 & -0.0413 & 1.2334 & -1.2216 & 0.0059 & 1.2334 & & & \\
\hline A2 & 1.2708 & -1.1809 & 0.0337 & 1.2483 & -0.1912 & -1.1809 & -1.1809 & & & \\
\hline A3 & -1.5562 & -0.7788 & -0.1423 & 0.1337 & 0.8659 & 1.4778 & 1.4778 & & & \\
\hline A4 & -1.3494 & -0.8580 & -0.3203 & 0.1123 & 0.7545 & 1.6609 & 1.6609 & & & \\
\hline $\begin{array}{l}\text { Euclidean } \\
\text { distance }\end{array}$ & 5.4997 & 3.3819 & 3.1064 & 3.1789 & 2.8639 & 1.2275 & & 3.2097 & 1.2473 & 5.7042 \\
\hline $\begin{array}{l}\text { The } \\
\text { integral } \\
\text { indicator }\end{array}$ & 0.04 & 0.41 & 0.46 & 0.44 & 0.50 & 0.78 & & & & \\
\hline
\end{tabular}

Source: Developed by the authors.

The results show that the main decrease in the integral index occurred in 2013, which is directly related to the high level of total labour turnover ratio. This is due, above all, to low pay, while having a relatively high level of productivity. 
4. Attracting modern innovative technologies as the basis for improving the competitiveness of light industry enterprises

In today's business environment, innovation activity is not only a decisive factor in the economic development of countries, but also a component of the enterprises' permanent development, and the basis for their competitiveness increasing in the relevant market segment.

Figure 2 shows the dynamics of changes in the number of innovatively active industrial enterprises in Ukraine, and defines their share in the total number of industrial enterprises in 2010-2018:

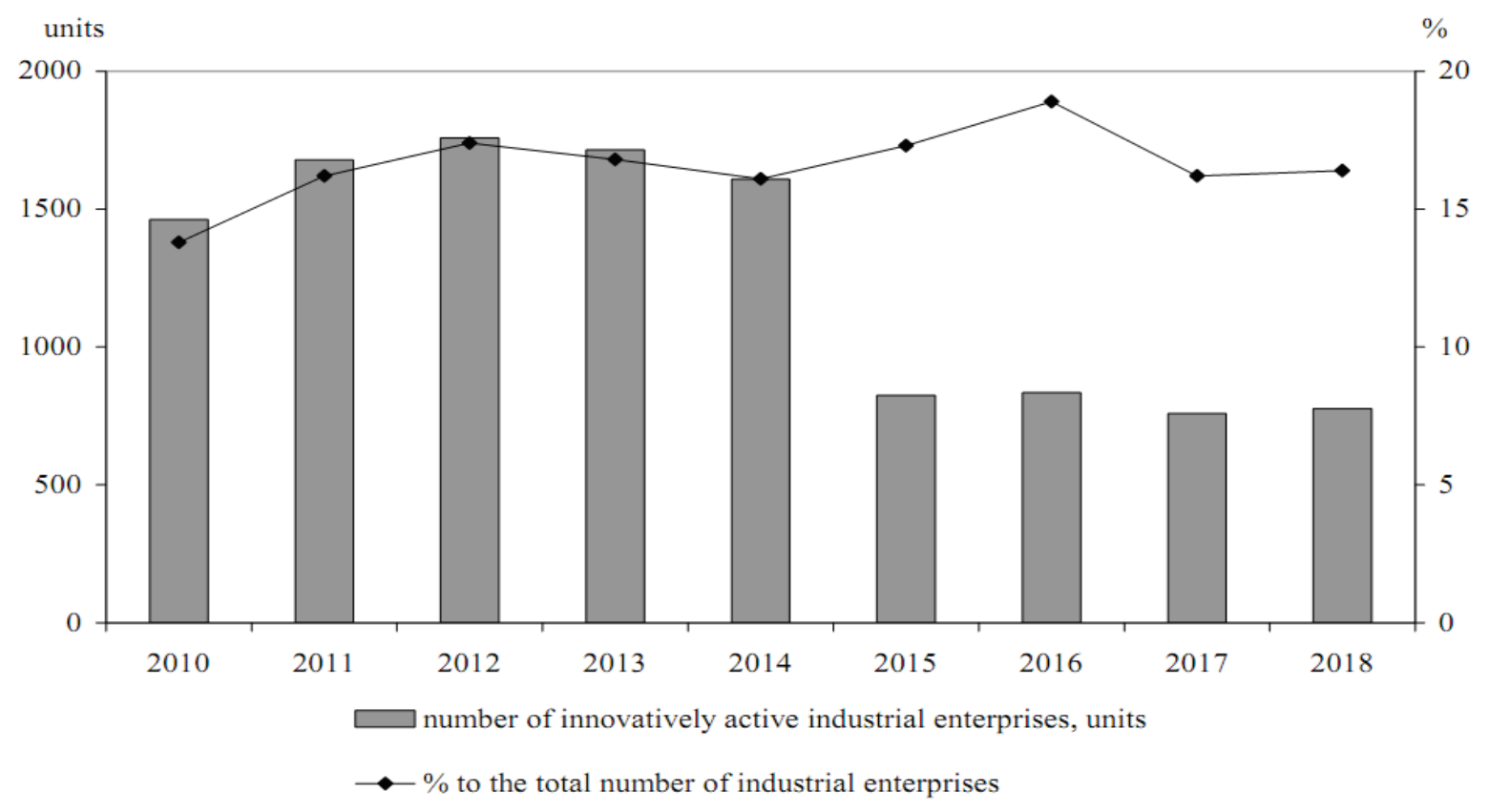

Figure 2. The dynamics of changes in the number of innovatively active industrial enterprises in Ukraine, and their share in the total number of industrial enterprises in 2010-2018.

Source: Compiled by the authors based on the official site of the State Statistics Service of Ukraine, 2018.

As can be seen from Figure 2, a very small number of industrial enterprises remain innovatively active in the national economy. Thus, in 2010-2018, the share of innovatively active industrial enterprises in Ukraine did not change significantly: it varied from $13.8 \%$ in 2010 to $18.9 \%$ in 2016 . In 2018, the share of innovatively active industrial enterprises amounted to $16.4 \%$, and the average for the studied period was $16.6 \%$. However, the number of innovatively active industrial enterprises in Ukraine in 2015-2018 halved compared with the period 2010-2014: the highest number is observed in 2012 (1,758 units), and the lowest in 2017 (759 units).

The negative tendency both in the change in the total number of industrial enterprises in Ukraine and in the change in the number of innovatively active industrial enterprises is a consequence of political instability in the country, the sharp devaluation of the national currency in 2014-2015, the imperfections of the legislative basis, the inability of the authorities to protect the property rights of investors, the lack of mechanisms of investment risk insurance, the shortage of internal resources for investment, etc.

Much of the cost of labour expenses and social deductions in light industry came from the lack of innovative specialised equipment to reduce the share of labour costs in the total production cost of goods. Thus, at the beginning of 2019, in textiles enterprises in the Kherson region (Ukraine), the degree of wear of sewing 
equipment was almost $70 \%$ (the share of sewing equipment in the total amount is $49 \%$ ). Almost a quarter of all sewing equipment is completely decommissioned, but still used in production; the residual value of more than half the equipment ranges from $3.7 \%$ to $5.9 \%$. The last purchase of equipment was carried out only in 2007. The 1967 equipment is still in use. A lack of government funding and high interest rates on loans do not allow the full purchase of innovative specialised equipment by light industry enterprises.

A flow chart for determining the feasibility of purchasing innovative specialised equipment is shown in Figure 3.

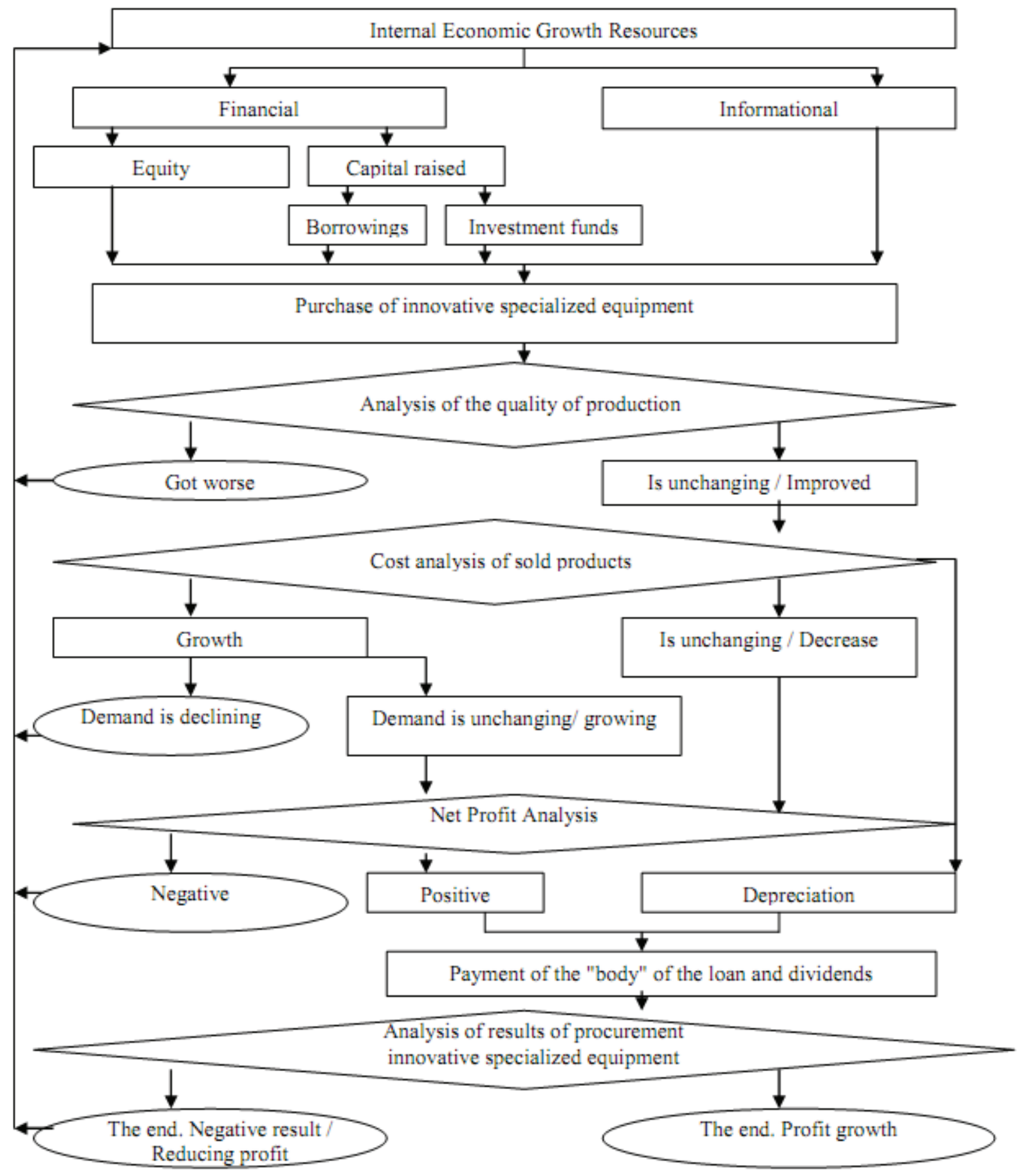

Figure 3. Flow chart for determining the feasibility of purchasing innovative specialised equipment.

Source: Developed by the authors. 
In today's business environment, Ukrainian business entities may receive additional preference when purchasing innovative foreign equipment and implementing it in the production process, on condition of creating industrial parks. Thus, in accordance with Section X of the 'Law on Industrial Parks' and Article 287, Paragraph 6 of the Customs Code of Ukraine, it is provided that the following shall be exempt from customs duties on imports into Ukraine: machinery, equipment and its components, materials not manufactured in Ukraine which are not excisable goods and are imported by the initiators of creation, i.e. economic entities, management companies of industrial parks for setting up industrial parks; machinery, equipment and its components, materials which are not manufactured in Ukraine and are not excisable goods, which are imported by participants in industrial parks for carrying out economic activity within the industrial parks.

At the same time, the released funds should be used by the appropriate entities to: set up industrial parks; introduce the latest technologies related to economic activity in the industrial parks; increase output and decrease costs by type of economic activity; carry out research activities in industrial parks; repay loans and pay back other borrowings used to set up industrial parks and implement economic activity in them, as well as to pay interest on such loans and borrowings.

The use of the privileges mentioned above when purchasing and implementing modern innovative technologies will allow for the optimisation of the cost of manufactured products, and an increase in the level of competitiveness of products, and the enterprise in general.

\section{Conclusions}

The results of the research conducted show that existing competitive advantages will be lost to enterprises that fail to appreciate the importance of the continuous and multifaceted implementation of innovations. It is necessary to ensure the formation of an innovative enterprise competitiveness management system, based on principles of priority for innovative, developed, scientific novelty, feasibility studies, legal justification, minimising risk and increasing the competitiveness of products, work, services, and the enterprise as a whole.

In order to determine the level of competitiveness of light industry enterprises in Ukraine, it is suggested to take into account factors that determine the level of information reliability and weapon effectiveness in the calculation. To evaluate the individual component competitiveness of the enterprise, it is suggested to calculate the integral assessment based on the use of taxonomic analysis.

It shows that the negative tendency both in the change in the total number of industrial enterprises in Ukraine and in the change in the number of innovatively active industrial enterprises is a consequence of political instability in Ukraine, the sharp depreciation of the national currency in 2014 and 2015, the imperfection of the legislative basis, the inability of the authorities to provide protection for investors' property rights, a lack of mechanisms for insuring investment risk, the scarcity of internal resources for investment, etc. There are also significant miscalculations by representatives of government structures regarding the involvement of advanced innovative technologies in economic processes and training, and the retention of qualified specialists in domestic business structures.

A flow chart determining the feasibility of purchasing innovative specialised equipment has been developed, which will simultaneously maximise the likelihood of attracting investment capital, with the simultaneous establishment of business cooperation with public authorities and local government.

Further research should focus on developing a justified methodology for determining the expert competence coefficient when measuring the information reliability index on markets for finished goods and production resources. 


\section{References}

Burtseva, T. A., Syzov, V. S., Tsen, O. A. (2005). Marketing Management. Moscow, Russia.

Customs Code of Ukraine: Code of Laws of Ukraine dated March 13, 2012 No. 4495-VI. Verkhovna Rada of Ukraine. Available at https://zakon.rada.gov.ua/laws/show/4495-17/print.

Economic Discussion Club. (2018). The position of Ukraine in the world ranking according to the Global Competitiveness Index 2017-2018. Available at_http://edclub.com.ua/analityka/pozyciya-ukrayiny-v-reytyngu-krayin-svitu-zaindeksom-globalnoyi-konkurentospromozhnosti-2

Illiashenko, S. M. (2003). Management of innovation development: problems, concepts, methods: Textbook: Educational edition. Sumy: University Book.

Ključnikov, A., Kozubíková, L., Sopková, G. (2017). The Payment Discipline of Small and Medium-sized Enterprises. Journal of Competitiveness, Vo. 9(2), p. 45-61. Available at_https://doi.org/10.7441/joc.2017.02.04.

Klymenko, S. M., Dubrova, O. S., Barabas, D. O., Omelianenko, T. V., Vakulenko, A. V. (n.d.). Enterprise Competitiveness Management: Textbook. Available: http:// posibniki.com.ua/catalog-upravlinnya-konkurentospromozhnistyupidpriemstva---klimenko-sm.

Ko, H., Min, K. (2019). Determinants of social expenditures in post-socialist countries. Economics and Sociology, Vol. 12(2), p. 253-264. doi:10.14254/2071- 789X.2019/12-2/15.

Koposov, H. O., Makarenko, S. M., Oliinyk, N. M., Kalynska, T. A. (2010). Ways to improve the competitiveness of enterprises in modern economic conditions. Taurian scientific bulletin, Vol. 68, p. 281-288.

Kot, O. V., Pavliuk, O. O. (2013). Defining the essence of the concept enterprise development. Business Inform, No. 8, p. 256-261.

Kozubikova, L., Kotaskova, A., Dvorsky, J., Kljucnikov, A. (2019). The impact of political factors` perception on suitability of international business environment: The case of startups. Economics and Sociology, Vol. 12(1), p. 61-79.

Kvasnytska, R. S., Ardashkina, N. S. (2009). Features of innovative activity of enterprises in modern conditions. Bulletin of Khmelnytskyi National University, No. 6, p. 247-251.

Malai, A. O. (2011). Ways to improve the investment climate in Ukraine. Economy and the state, Vol. 9, p. $102-105$.

Mas'ud, A., Manaf, N. A. A., Saad, N. (2019). Trust and power as predictors to tax compliance: Global evidence. Economics and Sociology, Vol. 12(2), p. 192-204.

Oliinyk, N. M., Makarenko S. M. (2017). Research of innovative activity and management of small enterprises' innovative activity in Ukraine. Management of economic processes and innovative development of industrial enterprises in the conditions of dynamic changes of the environment [collective monograph] / under the head. ed. Doctor of Economics, prof. M. V. Sharko. Kherson: PE Vyshemyrskyi V. S., p. 56-69.

On Amendments to Certain Legislative Acts of Ukraine in connection with the adoption of the Customs Code of Ukraine: Law of Ukraine dated March 13, 2012 No. 4496-VI. Verkhovna Rada of Ukraine. Available at_https:// zakon.rada.gov.ua/laws/show/4496-17/print.

On industrial parks: Law of Ukraine dated June 21, 2012 No. 5018-VI. Verkhovna Rada of Ukraine. Available at https:// zakon.rada.gov.ua/laws/show/5018-17/print.

On the regime of foreign investment: Law of Ukraine of March 19, 1996, No. 93/96-VR. Verkhovna Rada of Ukraine. Available at_https://zakon.rada.gov.ua/laws/show/93/96-\%D0\%B2\%D1\%80/print.

Porter, M. (2005). Competition. Trans. with English. Williams Publishing House.

Savchuk, A. V. (2001) A systematic approach to the analysis of the competitiveness of an industrial enterprise. Economist, Vol. 12, p. 58-61.

Statistical collection: Scientific and innovative activity of Ukraine. (2018). State Statistics Service of Ukraine. Available at http:// ukrstat.gov.ua.

Tiukha, I. V. (2012). Social and economic development of enterprises: essence and types of manifestations. Effective economy: Electronic professional periodical, No. 6. Available at http://www.economy.nayka.com.ua.

Tyukhtenko, N. A., Makarenko, S. M. (2016). Economic and mathematic models for staff planning at enterprises of all ownership forms. Actual problems of economics, Vol. 1, No. 175, p. 435-442.

Tyuhtenko, N. A., Makarenko, S. M., Oliinyk, N. M. (2018). Increasing competitiveness of the enterprise by improving logistic strategy of distribution of production and supply of raw materials. Scientific bulletin of Polissia, Vol. 2 (14), p. 56-63.

Tyukhtenko, N., Makarenko, S., Oliinyk, N., Gluc, K., Portugal, Ed., Rybachok S. (2019). Innovative development of the regions: cooperation between enterprises and state institutions. Marketing and Management of Innovations, Vol. 3, p. 354-365. Available at_http://doi.org/10.21272/mmi.2019.3-27.

Veliu, L., Manxhari, M., Podvorica, N., Fejza, E., Hyesni, V. (2018). Managing SMEs in a turbulent context: A case study from a Kosovan manufacturing company. Journal of Competitiveness, Vol. 10(1), p. 155-170.

Zachosova, $N$. (2019) Innovative approach in the estimatology of financial institutions economic security: possibilities of use in management and regulatory activity within the means of provision of the state financial security. Baltic Journal of Economic Studies, Vol. 5, No. 2, p. 45-56. 


\title{
PRAMONÉS İMONIU KONKURENCINGUMO VALDYMAS: UKRAINOS ATVEJIS
}

\author{
Nataliya Tyukhtenko, Serhit Makarenko, Galina Savina, \\ Nataliia Oliinyk, Yana Oleksenko, Serhit RybachoK \\ Chersono valstybinis universitetas, Chersono valstybinis technikos universitetas (Ukraina)
}

Santrauka

Didinti įmonès plètrą ir jos konkurencingumą, esant nestabiliai verslo aplinkai, galima tik veiksmingai taikant šiuolaikinius gamybos išteklių valdymo metodus ir nuolat diegiant inovatyvias technologijas visose ekonominès veiklos srityse. Novatoriška pramonès įmonių veikla yra pagrindine jų konkurencingumo sąlyga, tą procesą būtina sistemingai valdyti. Skatindamos novatorišką vystymąsi, vietinès įmonės gebės sparčiai reaguoti ị rinkos pokyčius, greitai ịveikti ekonominės krizès padarinius ir tai lems atlyginimų didejjimą, kas pagerins socialinę būklę. Straipsnyje siekiama įvertinti Ukrainos lengvosios pramonės įmonių konkurencingumą ir nustatyti tai užtikrinančius veiksnius, parengti rekomendacijas dèl galimų investicijų ir modernių inovatyvių technologijų diegimo. Kaip tyrimo objektas pasirinktos Ukrainos lengvosios pramonės imonès. Siekiant nurodyto tikslo, taikyti šie bendrieji moksliniai ir specialieji metodai: ekspertinis metodas, siekiant nustatyti kokybinių ir kiekybinių rodiklių įtaką darbo išteklių naudojimo veiksmingumui; ekonominis ir matematinis - nustatyti konkurencingumo indeksą ir integruotą darbo išteklių naudojimo veiksmingumo ivvertinimo rodiklį; abstraktus loginis - apibendrinti ir formuluoti išvadas.

Atliktų tyrimų rezultatai atskleidè, kad esamus konkurencinius pranašumus praras tos įmonės, kurios neįvertins nuolatinio ir daugialypio inovacijų diegimo svarbos. Būtina sukurti inovatyvios ịmonės konkurencingumo valdymo sistemą, kuri būtų pagrịsta novatoriškumu, mokslo naujovėmis, parengtų galimybių studijų rezultatais, teisiniu reglamentavimu, tai minimizuotų riziką ir padidintų konkurencingumą. Atskleista, kad neigiama bendro Ukrainos pramonès įmonių ir naujų aktyvių pramonės įmonių skaičiaus pokyčio tendencija yra Ukrainos politinio nestabilumo, staigaus nacionalinès valiutos nuvertejjimo 20142015 metais pasekmè, įstatymų bazès netobulumas, valdžios institucijų negebejjimas užtikrinti investuotojų nuosavybès teisių apsaugos, investavimo rizikos draudimo mechanizmų, vidinių išteklių investicijoms trūkumas ir kt. Paskaičiuota, kad i ekonominius procesus neįtraukus pažangių inovatyvių technologijų ir neparengus kvalifikuotų specialistų bei negebant organizacijose išlaikyti specialistų, ekonomikos augimas neįmanomas.

Sukurta modernios specialios įrangos įsigijimo galimybių schema, kuri padidins investicinio kapitalo pritraukimo tikimybę, kartu užtikrins verslo bendradarbiavimą su valdžios institucijomis ir vietos savivalda.

PAGRINDINIAI ŽODŽIAI: vadyba, konkurencingumo indeksas, darbo ištekliai, modernios technologijos.

JEL KLASIFIKACIJA: M 11, M 12, M 13

Received: 2019-12-28

Revised: 2020-01-25

Accepted: 2020-01-30 